\title{
Towel curettage for a new definition of postpartum period after cesarean section
}

\author{
Suzan Elsharkawy*
}

Department of Obstetrics and Gynecology, Alexandria Faculty of Medicine, Alexandria University, Egypt

Received: 18 April 2018

Accepted: 23 May 2018

\section{*Correspondence:}

Dr. Suzan Elsharkawy,

E-mail: samirsuzan6@gmail.com

Copyright: (C) the author(s), publisher and licensee Medip Academy. This is an open-access article distributed under the terms of the Creative Commons Attribution Non-Commercial License, which permits unrestricted non-commercial use, distribution, and reproduction in any medium, provided the original work is properly cited.

\section{ABSTRACT}

Background: The objective of the present study was to compare effect of towel curettage as a new technique, to no curettage in caesarean section on postpartum period duration and hemoglobin level.

Methods: Prospective, randomized controlled trial included 403 eligible participants that were attending Elshatby maternity hospital in the duration of this study (2016) and scheduled for primary caesarean section. The patients were randomized into two groups A and B. Group A had towel curettage after manual separation of the placenta, where the decidua and the placental bed were thoroughly curetted by a surgical towel. Group B had manual separation of placenta only.

Results: Towel curettage actually shortens the puerperal bleeding days by almost a week and the volume of blood loss by around half a gram/dl, a situation that could be of great concern in the developing countries where iron deficiency anemia can be considered endemic.

Conclusions: Suzan towel curettage is a new, simple, cheap methods that deceases duration of puerperium and the amount of useless blood loss post-partum, which may save a good percentage of women from suffering the negative influences of iron deficiency anemia.

Keywords: Anemia, Bleeding, Postpartum period

\section{INTRODUCTION}

The puerperium (postpartum period or postnatal period) is the period following delivery, during which the hormonal levels and most of the changes in the organs and systems evoluted during pregnancy involute back to its prepregnancy condition. The duration of puerperium starts immediately after the birth of a child and lasts for six weeks during which complete physiological and psychological adjustment occurs, and despite of the indisputable importance of this part of human reproductive process it does not get an adequate attention as the other aspects of obstetrics and gynecology. ${ }^{1}$

Iron deficiency is the commonest Nutritional deficiency disorder in the world, affecting more than two billion people. World Health Organization (WHO) show that iron deficiency anemia (IDA) in pregnancy is a big problem with a prevalence over $14 \%$ of pregnant women in the first world countries to an average of $56 \%$ in the third world countries. ${ }^{2-3}$

Anemia after the delivery of a child is a common problem throughout the world with the highest prevalence in the developing counties where it represents a major cause of maternal morbidity and mortalities. It has been estimated that $20 \%$ of maternal deaths related to delivery, are caused mainly by peripartum hemorrhage and anemia, at the same time where hemorrhage takes all the focus and gets the big attention, post-partum (pp) anemic state takes almost little care by researchers. ${ }^{4}$

Anemia of postpartum period is caused by moderate-toheavy blood loss just before, during or after delivery that 
may produce acute or subacute anemia, that is confirmed by measurement of the hemoglobin concentration 24-48 hours after delivery.

From the scanty data available, it is suggested that postpartum anemia should be defined as a hemoglobin concentration of $<11 \mathrm{~g} / \mathrm{dl}$ at 1 week postpartum and $<12$ $\mathrm{g} / \mathrm{dl}$ at 8 weeks postpartum, with a prevalence that may reach up to $70-80 \%$.

In developing countries. ${ }^{5}$ Peripartum bleeding has a great impact on postpartum iron requirements and may lead to rapid depletion of iron reserves and elicit long-standing iron deficiency and IDA in the postpartum period.

The consequences of PP anemia will have a negative influence on the quality of the mother and her baby. fatigue, shortness of breath, high heart rate, blurring of vision, disturbed endocrine functions, impaired regulation of temperature, increased risk of infections, impaired lactation and baby nutrition, etc. ${ }^{6}$

The psychical and behavioural consequences include many possibilities like: impaired cognitive functions, irritability, mental instability, distress, postpartum depression and it may influence mother-infant interactions. $^{7}$

Furthermore, PP anemia impairs. Anemic mothers will improve following treatment with iron. ${ }^{6-7}$

Vaginal discharge (or lochia) is grossly bloody (lochia rubra) for 5 to 7 days which may extend for longer duration in a good percentage of cases, over the next 10 to 12 days, it turns to pale brown (lochia serosa) and finally to yellowish white (lochia alba).

After 4 weeks' post-partum, eschar from the placental site sloughs off and bleeding occurs. Total blood loss during the puerperium is an average of $250 \mathrm{ml}$, which may be much higher in operative deliveries.

If we are able to decrease these amount of useless bleeding, we will help the woman to save a considerable volume of her blood and iron stores. ${ }^{8}$

The aim of the present study was to compare effect of towel curettage as a new technique, to no curettage in caesarian section on postpartum period duration and hemoglobin level. We hypothesized that towel curettage will increase hematogram and decrease postpartum bleeding days.

\section{METHODS}

Single-centric, prospective, randomized controlled trial. Randomization was computer generated by a third party not otherwise involved in the trial.
403 eligible participants were women attending Elshatby maternity hospital in the duration of this study (2016) and scheduled for primary caesarean section. The women gave written informed consent. Women with having preoperative hemoglobin level of less than 10.5 gmldl, any positive medical history or postpartum hemorrhage were excluded.

The patients were randomized into two groups A and B. Group A had towel curettage after manual separation of the placenta, where the decidua and the placental bed were thoroughly curetted by a surgical towel. Group B had manual separation of placenta only.

All patients had done a hemoglobin level after 1 hour postoperative and after 6 weeks postpartum (as an indicator of the amount of blood loss) as a primary outcome and the two groups were also compared according to the number of red lochia days' post-partum, and the duration of post-partum period as a secondary outcome. No postpartum iron replacement therapy was given in both groups.

To ensure that the study was carried out in a responsible manner from a research ethical point of view, RCTs have to be approved by a research ethics committee before it started, and that the rights, safety, and wellbeing of the patients are protected, at the same time, the possibility is being created for the development of recent, valuable knowledge.

\section{RESULTS}

A total of 403 women were randomized into 202 cases had towel curettage after manual placental separation and 201 cases with manual separation only.

The two groups were compared according to their hemoglobin levels one hour postoperative and after 6 weeks postpartum, also compared according to the number of red lochia days' post-partum, and the duration of post-partum period as well.

As regard the level of hemoglobin after one-hour postoperative the was no significant differences between both groups, however in its level after 6 weeks' post-partum, the was a significant difference with evident less blood loss in the curettage group as manifested by a less decrease in hemoglobin levels by about half a gram/dl, as shown in Table 1.

And as regards the duration of the red lochia (bleeding days), there was a significance in favor of the curettage group, with a shorter duration mean equals 6 days less in the curettage group and as a whole duration of the puerperium which is shorter by almost two weeks, as shown in Table 2. 
Table 1: Comparison between the two studied groups according to hemoglobin (hg) level.

\begin{tabular}{|c|c|c|c|c|}
\hline Hg level (gmldl) & Group A $(n=202)$ & Group B $(n=201)$ & Test of Sig. & $\mathbf{P}$ \\
\hline \multicolumn{5}{|l|}{ After 1 hour } \\
\hline Median (Min-Max.) & $10.8(10.5-13.8)$ & $11(10.2-14)$ & \multirow{2}{*}{$\mathrm{t}=0.233$} & \multirow{2}{*}{0.816} \\
\hline Mean \pm SD & $12.1 \pm 0.9$ & $12.2 \pm 0.85$ & & \\
\hline \multicolumn{5}{|l|}{ After 6 weeks } \\
\hline Median (Min-Max.) & $10.5^{\#}(9.8-13.2)$ & $10.1^{\#}(8.7-12.5)$ & \multirow{2}{*}{$\mathrm{t}=7.042^{*}$} & \multirow{2}{*}{$<0.001^{*}$} \\
\hline Mean \pm SD & $10.9 \pm 0.9$ & 10.30 .8 & & \\
\hline \multicolumn{5}{|c|}{ Decrease in $\mathrm{Hg}$ level (gmldl) } \\
\hline Median (Min-Max.) & $0.4(-0.2-1)$ & $0.9(0.1-3.4)$ & \multirow{2}{*}{$\mathrm{U}=5199.0^{*}$} & \multirow{2}{*}{$<0.001^{*}$} \\
\hline Mean \pm SD & $0.4 \pm 0.3$ & 10.6 & & \\
\hline
\end{tabular}

Table 2: Comparison between the two studied groups according to lochia duration.

\begin{tabular}{|c|c|c|c|c|}
\hline Lochia duration (days) & $\begin{array}{l}\text { Group A } \\
(\mathrm{n}=202)\end{array}$ & $\begin{array}{l}\text { Group B } \\
(\mathrm{n}=201)\end{array}$ & $\begin{array}{l}\text { Test of } \\
\text { Sig. }\end{array}$ & $\mathbf{P}$ \\
\hline \multicolumn{5}{|l|}{ Red } \\
\hline Median (Min-Max.) & $3(2-7)$ & $9(6-21)$ & \multirow{2}{*}{$\begin{array}{l}t= \\
27.662\end{array}$} & \multirow{2}{*}{$<0.001^{*}$} \\
\hline Mean \pm SD & $3.7 \pm 1$ & $9.6 \pm 2.9$ & & \\
\hline \multicolumn{5}{|l|}{ Non-red } \\
\hline Median (Min-Max.) & $7(4-11)$ & $12(7-20)$ & \multirow{2}{*}{$\begin{array}{l}\mathrm{t}= \\
21.010\end{array}$} & \multirow{2}{*}{$<0.001^{*}$} \\
\hline Mean \pm SD & $6.8 \pm 1.7$ & $12.8 \pm 3.7$ & & \\
\hline \multicolumn{5}{|c|}{ Puerperium duration (days) } \\
\hline Median (Min-Max.) & $10(7-16)$ & $22(13-35)$ & \multirow{2}{*}{$\begin{array}{l}\mathrm{t}= \\
32.430\end{array}$} & \multirow{2}{*}{$<0.001^{*}$} \\
\hline Mean \pm SD & $10.5 \pm 1.9$ & $22.4 \pm 4.9$ & & \\
\hline
\end{tabular}

$\mathrm{t}, \mathrm{p}$ : $\mathrm{t}$ and $\mathrm{p}$ values for Student t-test for comparing between the two groups; $\mathrm{U}, \mathrm{p}$ : $\mathrm{U}$ and $\mathrm{p}$ values for Mann Whitney test for comparing between the two groups; *: Statistically significant at $\mathrm{p} \leq 0.05$; \#: Significant with 1 hour

\section{DISCUSSION}

For more than 10 years ago, the author used to do the technique of "towel curettage" to all her patients, to make sure that she had "cleaned up " the uterus from all the trophoblasts and fetal membranes.

The idea of the study started when she noticed a repeated patients' observations about a shorter puerperium and a less puerperal bleeding than they used to have in pervious cesarean sections, a condition they felt happy for.

The author decided to study the phenomena in a more scientific way, designed the study in a comparative prospective manner and the results came to declare that the new simple, cheap method actually shortens the puerperal bleeding days by almost a week and volume of blood loss by around half a gram/dl, a situation that could be of great concern in the developing countries where iron deficiency anemia can be considered endemic, not only it saves grams of iron stores, but also decreases days of puerperium where the women have to abstain from sexual intercourse and prayers in Muslim counties.

After revising the literature, there was nothing about curetting the uterine cavity with a towel in each case of cesarean section for any prophylactic or therapeutic indication. Towel curettage is a completely new technique and we named it after the author name as " Suzan Curettage "

Marcyniak M et al studied the indications for curettage directly after delivery and compared it with histologic findings, they found no fragments of placental or membrane tissue in $75 \%$ of the patients experiencing post-partum bleeding. ${ }^{9}$

Almansa $\mathrm{C}$ et al performed a retrospective study on 42 puerperal curettage cases after cesarean section, the indications for curettage were fever in 21 case, methrorraghia in 11 case and residual trophoblastic tissue in 10 cases only. ${ }^{10}$

These findings may indicate that Suzan curettage is not done for removal of remnants of trophoblasts but mainly to decrease postpartum bleeding and duration.

\section{CONCLUSION}

Suzan towel curettage is a new, simple, cheap methods that deceases duration of puerperium and the amount of useless blood loss post-partum, which may save a good percentage of women from suffering the negative influences of iron deficiency anemia.

Funding: No funding sources

Conflict of interest: None declared 
Ethical approval: Not Required

\section{REFERENCES}

1. American College of Obstetricians and Gynecologists. ACOG Practice Bulletin: Clinical Management Guidelines for ObstetricianGynecologists Number 76; 2006: postpartum hemorrhage. Obstetrics and Gynecology. 2006;108(4):1039.

2. Benoist BD, McLean E, Egll I, Cogswell M. Worldwide prevalence of anaemia 1993-2005: WHO global database on anaemia. Worldwide prevalence of anaemia 1993-2005: WHO global database on anaemia. 2008.

3. Milman N: Iron deficiency and anaemia in pregnant women in Malaysia- still a significant and challenging health problem. J Preg Child Health. 2015;2:168.

4. Milman N. Postpartum anemia I: definition, prevalence, causes and consequences. Ann Hematol. 2011;90:1247-53.

5. Oyelese Y, Ananth CV Postpartum hemorrhage: epidemiology, risk factors, and causes. Clin Obstet Gynecol. 2010;53:147-56
6. Bergmann RL, Richter R, Bergmann KE, Dudenhausen JW: Prevalence and risk factors for early postpartum anemia. Eur J Obstet Gynecol Reprod Biol. 2010;150:126-31

7. Perez EM, Hendricks MK, Beard JL.: Mother infant interaction and infant development are altered by maternal iron deficiency anemia. J Nutr. 2005; 135:850-5.

8. Berghella V, Baxter JK, Chauhan SP. Evidencebased surgery for cesarean delivery. Am J Obstet Gynecol. 2005;193(5):1607-17.

9. Marcyniak M, Czajkowski K, Deregowski K, Hamela-Olkowska A, Jalinik K., Curettage immediately after delivery. Ginekol Pol. 2002;73(12):1213-7.

10. Almansa C, Camaño I, Villar O, Montañez D, Vallejo P, García-Burguillo A. Puerperal curettage after cesarean section delivery. J Perinat Med. 2013;41(3):267-71.

Cite this article as: Elsharkawy S. Towel curettage for a new definition of postpartum period after cesarean section. Int J Reprod Contracept Obstet Gynecol 2018;7:2537-40. 